\title{
Modeling of Semantic Structure of Similative Phraseological Units
}

\author{
Victoria V. Dobrova, ${ }^{1, *}$, Vladimir M. Savitsky, Lilia R. Nurtdinova, Olga A. Kistanova, and Natalia V. Ageenko \\ ${ }^{1}$ Samara State Technical University, Department of Foreign Languages, 244 Molodogvardeyskaya Str., Samara 443100, Russia
}

\begin{abstract}
The problem of modeling of semantic structure of similative phraseological units is described. With the use of formal meta language SESAME invented for the purposes of the conducted semantic analyses (a meaningful acronym of Standard Events and Situations Artificial Meta-language) on the basis of frame-scenario models, the authors made an attempt to analyze the transferred meaning and in particular the degree of modeling potential, the degree of explicitness / implicitness, the degree of semantic dividedness / integrity and the scale of the denotative area of English similative phraseological units. Similative phraseological units under consideration can be comparative, metaphoric or allegoric.
\end{abstract}

\section{Introduction}

In this paper, the specific features of linguistic units with a "two-tier" semiotic structure are considered - they are characterized by the presence of literal and figurative semantic plans. Identifying and comparing the structure of these plans with the help of the frame method allows drawing conclusions of typological and linguistic-semiotic character.

As a material, we chose such "two-tiered" language units as phraseological units. To compose frames of phraseological units, it is required to correlate their semantics with categories of meta-language. We will demonstrate the method of translation from the natural (English) language to the formalized meta-language of SESAME, a translation performed during the practical application of this meta-language in order to reveal the semantic structure of phraseological units. SESAME is a meta-language invented for the purposes of our semantic analyses, a meaningful acronym of Standard Events and Situations Artificial Meta-language [1].

\section{Semantic structure of phraseological units}

\subsection{The essence and specificity of the simulative transfer of meaning}

It is well known that the semantics of a linguistic sign can have a two-tiered structure [2;3]. The upper tier makes up the plan for the content of the sign, and the previous tier forms the upper level of the expression plan and performs the function of the internal form of the sign.

Language semantics is divided into semasiology and onomasiology. The notion of the "onomasiological level" was introduced by M.V. Nikitin [4]. He understood the first onomasiological level as a tier of semantics of the sign on which his literal meaning is located, and the second - as the one on which its derivative, figurative meaning is located.

The semantic structure of the second onomasiological level can be modeled on the basis of the use of the frame method. The models of this level are more complex than those that describe the semantic structure of the first onomasiological level. This is due to the fact that they cover both levels and show the nature of the motivational connection between them. In the present paper, the frame modeling of the semantic structure of the second onomasiological level is demonstrated on the material of English phraseological units. The choice of the material is explained by the fact that the semantics of all phraseological units have a two-tiered structure and clearly demonstrates the regularities that we are considering.

A number of linguistic works have demonstrated how great the diversity of the types of semantic transfer in phraseology is. In our paper, only similative transfer is considered. The material of the analysis was mainly verbal phraseological units.

The term similative (from Latin "similāre") means such an assimilation of objects in which not thematically related, class related objects ( $a$ horse and an ass, a needle and a pin, a sea and a lake) are subject to comparison, but the thematically remote, dissimilar objects - such as the heart and a lone hunter (C. McCullers. Heart Is a Lonely Hunter).

M.V. Nikitin [4] made a distinction between classification and similative comparison because the first establishes the place of the objects to be compared in the main, conceptual-categorization picture of the world and the second is a quasi-classification. Nevertheless, it reflects the real (objective structural-functional or subjective emotionalevaluative) semblance of referents that is not considered in the classification model of the world, and thereby enriches

\footnotetext{
* Corresponding author: victoria_dob@mail.ru
} 
cognition, which makes it possible to talk about its modeling function. These and other comparisons coexist on the principle of complementarity.

It is important to note that in the case of a similative comparison, the comparisons are not coincidental, but they are made by specially selected objects unlike the classification comparison. During the classification of objects, a hierarchy of levels of abstraction arises: from single objects to species, from them to genera. In the case of similative comparison not all integral signs of the theme and image are taken as a basis, and plus there is no abstraction from their distinctive features as they play a leading role in creating an aesthetic sense.

Our analyses showed that the essentiality of the features and the depth of the simulation in the similative comparison are fundamentally different from those in the classification comparison. What is private, small, random from a conceptual point of view, sometimes turns out to be highly significant, common and profound - with an aesthetic point of view.

Unlike the classification comparison, the figurative basis of the similative comparison may not necessarily be a significant feature, but any feature. But, with a different approach, it can be argued that in the similative comparison, the essential features are not those that are considered to be such in the case of a classification comparison.

\subsection{Semantic integrity of similative phraseological units}

As an example, let us consider the English idiom to cast stones at smb. ("to bring charges against someone"). Its basis for comparison can be represented by a frame:

FRAME "ATTACK"

(to cast stones at somebody)

1) INITIAL SITUATION: HAS $x, i$. IF (USES $x, i$ ) THEN (DAMAGES $z$ ).

2) DESIRE $x$ : WANTS $x$ (DAMAGES $z$ ).

3) INTENTION $x$ : INTENDED $x$ (CAUSES $x$ (DAMAGES

z)).

4) ACTION $x$ : USES $x, i$.

5) CONSEQUENCES: DAMAGES z.

Terminal interpretation:

\begin{tabular}{|l|c|c|c|c|}
\hline $\begin{array}{l}\text { terminals } \\
\text { slots }\end{array}$ & $\begin{array}{c}\mathrm{x} \\
\text { (aggresso } \\
\mathrm{r} \text { ) }\end{array}$ & USES & $\begin{array}{c}\mathrm{i} \\
\text { (weapon) }\end{array}$ & $\begin{array}{c}\mathrm{z} \\
\text { (victim } \\
\text { ) }\end{array}$ \\
\hline 1) meaning & smo & brings & charges & $\begin{array}{c}\text { against } \\
\text { smb. }\end{array}$ \\
\hline $\begin{array}{l}\text { 2) inner } \\
\text { form }\end{array}$ & smo & throws & stones & at smb. \\
\hline $\begin{array}{l}\text { 3) surface } \\
\text { level }\end{array}$ & smo & casts & stones & at smb. \\
\hline
\end{tabular}

The frame clearly shows that all levels of the structure of this idiom are isomorphic to each other. Each lexeme in its composition performs an independent nominative function both at the level of meaning and at the level of the internal form: casts - "puts forward / throws", stones - "accusations / stones", at - "against / in". This phraseological unit consists of words; in other words, it is semantically divided.
As we see, not all phraseological units possess the property of semantic integrity. Let us consider the phraseological unit to buy a ranch ("to die"). At the level of meaning, we are dealing with a one-place predicate, which argument is the actor in the role of "subject of change," and at the level of the internal form - with the poly-predicative frame "Acquisition." There is an anisomorphism of the role structures of the content plan and the expression plan. As a result, individual lexemes in the phraseological unit have no independent meanings. Here we have semantically integral phraseological unit.

On the scale "joint - integral phraseological units", the intermediate ranks are located between the poles. For example, the phraseological unit to build castles on the sand is separated in the area to build (this verb in this phraseological context has an independent portable meaning "to create") and is integral in the area of castles on the sand. This combination of lexemes literally means the location of the actor, and in the figurative sense - the presence of the actor's property. The anisomorphism of semantic plans on this area prevents the existence of independent meanings for lexemes. The lexical component to build in the composition of this phraseological unit at the second onomasiological level is a word, and the remaining lexemes are not.

These three types of similative transfer correspond to three subclasses of the structural-semantic class of similative phraseological units, distinguished by the degree of integrity of their meanings. Semantic integrity has long been considered one of the categorical properties of phraseological units. It is understood as the dispersal of the general meaning of phraseological unit throughout the combination of lexemes, the impossibility (in the case of ultimate integrity) to single out in the general meaning of phraseological unit the particular meanings assigned to individual lexemes, which deprives the lexemes of an independent nominative function.

In the considered phraseological models, one of the factors of the semantic integrity of phraseological units is demonstrated - the absence of a through isomorphic correspondence between phraseological meaning, internal form and surface structure.

If each of the lexical components of phraseological unit is isomorphic to one element of the internal form and to one element of the meaning of phraseological unit, then this phraseological unit belongs to a subclass of minimally integral ones. However, if not all lexemes have a one-to-one correspondence, then it belongs to a subclass of mediumintegral phraseological units. In the absence of an isomorphism, we are dealing with a subclass of maximum integral phraseological units.

\subsection{The relationship between the meanings of lexical components of captions/numbering}

There is one more factor of the semantic integrity of phraseological units. According to V.P. Zhukov, it is "the forces of mutual attraction" of lexemes in the composition of phraseological unit [5].

Not a single phraseological unit can be completely semantically divided; even in the presence of a complete isomorphism of semantic plans, the lexical components of a 
phraseological unit are to some extent semantically welded together. G.L. Permyakov [6] pointed out that the set expression The pen is stronger than the sword is not a phraseological unit, because it is idiomatic not at the level of lexical units but at the level of the whole expression. We see three different independent images, not even thematically linked: the pen symbolizes the propaganda effect on the masses, the stronger - the greater effectiveness of the impact, the sword - the repression. This expression is as semantically divided as any literal combination of words / utterance. Phraseological imagery begins where semantic interdependence of transferred meanings arises. By the types of this dependence, the models of simulative transfer are divided into categories.

Rank 1. Phraseological units that fit into the model of this category consist of lexemes that have the same transferred meanings that are realized when used in variable contexts and are fixed in dictionaries, and these are their only or basic transferred meanings. As an example, let us consider the phraseological unit to cast pearls before swine. Explanatory dictionaries fix the following meanings of the words entering into it:

to cast - 1. to throw, to fling; 2. (fig.) to give, to provide; pearls - 1. a kind of jewel; 2. (fig.) a valuable thing or person;

swine - 1. a pig, a hog; 2. (fig.) a rude and ignorant person.

According to the Oxford Dictionary, this phraseological unit means "to give something valuable to those who cannot appreciate it". Comparison of the definitions of lexical components with the general definition of this phraseological unit clearly demonstrates that its meaning consists of independent transferred meanings of individual lexical components. And yet the lexical components of this phraseological unit are more semantically welded to each other than the components of the Pen's are stronger than the sword expression. The factor that determines their cohesion is the unity of the common image, the belonging of all the images included in it to a single scenario.

Rank 2. In other cases, the lexemes may have several transferred meanings, none of which is clearly dominant. This is, for example, the lexeme fire. In the Oxford explanatory dictionary, the following transferred meanings of this lexeme and phraseological contexts, in which these values are realized, are given:

1) "a destructive force": to put smth. to fire and sword, to be between two fires, to go through fire and water;

2) "home comfort": fire that lights us at a distance, to keep fire;

3) "passion, excitement": to blow fire, to strike fire;

4) "knowledge, enlightenment": to light the sacred fire, Promethean fire.

The meanings of the fire lexeme are also implemented in variable contexts, but due to the polysemy the lexical components of the listed phraseological units are more semantically welded to each other than in the first-ranked phraseological units, as the actualization of a given meaning depends more on the exact constant context of phraseological unit.

Rank 3. There are such phraseological units, which lexical components acquire transferred meanings only in the constant context. Such meanings are generated as a result of the interaction of the meanings of the lexemes. So, for example, in phraseological unit (to feel like) a fish out of water, the fish and water lexemes get interdependent transferred meanings only in close semantic interaction with each other: fish is the "actor in relation to the habitual area", water is "habitual area for the actor". These meanings are derived from each other. The semantic integrity of lexical components in this category of phraseological units is higher than in the two described above. The same category includes phraseological units: to lead a cat-and-dog life, to put all one's eggs into one basket, to take two bites of a cherry, etc.

Rank 4. In phraseological units that fit into the model of this group, lexical components do not have their own transferred meanings. This is the maximum semantic integrity. This includes such phraseological units as to beat the air, to see wolf, to drive one's hogs to market, etc. Due to the peculiarities of verbal similative phraseological units, most of them belong to the previous groups. In the 4th group, there are more substantive phraseological units (white elephant, blue rose, red herring, etc.), as well as other non-verbal phraseological units.

\section{FRAME "USELESS ACTION"}

(to beat the air)

1) INITIAL SITUATION: IF (MAKES $x, A$ ) THAT (DOES NOT HAVE $\mathrm{x}, \mathrm{v})$.

2) EPISTEMIC STATE $x$ : BELIEVES $x$ ((IF $(x, A)$ MAKES (HAS $x, v)$ ) At the time $t 1$.

3) DESIRE $x$ : (WANTS $x($ HAS $x, v)$ ) At the time $t 2$.

4) ACTION $x$ : (MAKES $x$, A) AT TIME $t 3$.

5) FORECAST OF CONSEQUENCES: (DOES NOT HAVE $\mathrm{x}, \mathrm{v}$ ) at $\mathrm{t} 4$.

\section{6) CONCLUSION-EVALUATION: INCONSISTENT} (ACTION $x)$.

Terminal interpretation:

\begin{tabular}{|l|c|c|c|}
\hline $\begin{array}{l}\text { terminals } \\
\text { slots }\end{array}$ & $\mathrm{X}$ & MAKES A & $\mathrm{V}$ \\
\hline 1) transferred plan & & & \\
\hline 2) literal plan & smo & beats the air & \\
\hline 3) surface structure & smo & beats the air & \\
\hline
\end{tabular}

Empty cells in the above matrix can be filled with situationally conditioned variables. Here is an illustrative example from the dictionary: If they want to make, they are beating the air (Merriam-Webster Dictionary). In this case, the cell $\mathrm{x}$ is filled with the pronoun they, the cell MAKES A - punishing him, cell v - to make Johnny a good boy.

The above-mentioned frame clearly shows that a phraseological unit containing only one verb may in fact have a very complex poly-predicative semantic structure. Its description with the help of ordinary language means (such as dictionary interpretations of the motivation of phraseological units), convenient for lexicographic purposes, there is no sufficient accuracy for demonstrating the nature of the structural relationship of the semantic plans of phraseological units. Meanwhile, the establishment of the degree of isomorphism of plans is essential for solving a number of phraseological problems.

\subsection{Means of reality modeling in the semantics of similative phraseological units}


The class of similative phraseological units can be divided into three subclasses: metaphorical, allegorical and comparative phraseological units. Each of them corresponds to a subclass of phrase-forming models. These subclasses are distinguished by the way of modeling the extralinguistic reality in the structure of phraseological units.

Metaphorical and comparative phraseological units are analyzed in detail in the linguistic literature, whereas allegoric phraseological units are given less research attention. However, many linguists do not make a clear distinction between metaphorical and allegorical phraseological units. Meanwhile, the latter, while in fact similar to phraseological metaphors, at the same time have several significant differences from phraseological metaphor as in the structural aspect (they are constructed according to several other schemes) and in the functional aspect (in their sign structure they model the world around them somewhat differently).

In the process of the allegorical interpretation of the image, a transfer is carried out, firstly, to a different thematic sphere, and secondly, to a higher level of generalization. Allegory can be defined as a figurative construction that performs a symbolic (modeling and communicative) function, and has the property of polyinterpretation, the ability to form around itself a field of situational interpretations within the framework of the invariant fixed in the image. In separate speech situations, the skeletal scheme of the allegorical image is overgrown with the "flesh" of situational meanings. A.F. Losev considered as one of the main properties of the allegory the fact that it can "decompose into an infinite series," and have an almost unlimited number of private interpretations [7].

Specificity of allegorical imagery in comparison with the metaphorical one is that it is asymmetric. "In a true metaphor, it is impossible to say which moment is an explanation, and which is an explanatory one," A.F. Losev [7]. Let us compare:

Lightly waveth the birch tree // When the glad day is dying, // And the soft wind seeks to woo her // Through her branches sighing. (The Birch Tree and the Maiden)

It is really difficult to determine which component of the metaphor - virgin or birch - is the image and which is the theme.

In the allegory, however, the image is exact and sensualvisual, while the theme is an abstract concept. For example, using the image of the garden of unripe fruit, $\mathrm{H}$. MacDiarmid characterized the youth (H. MacDiarmid, Complete Poems). Or another example: O my luve's like a red, red rose // That's newly sprung in June (R. Burns, O My Luve).

The difference between the above-mentioned types of imagery in phraseological units can be explained through the antithesis of the concepts "meaning" and "situational meaning." In phraseological metaphor, linguistic meaning and its verbal meaning coincide in basic features. For example, the phraseological unit to be a sheet in the wind in any context means the same thing: "be a bit tipsy". Unlike metaphorical, allegorical phraseological units, they can have different situational-speech meanings within a single abstract meaning.

Poly-interpretation is a specific feature of allegorical phraseological units [8], but this is also a vague concept, therefore it is not easy to draw a line between metaphorical and allegorical phraseological units.

By the nature of their imagery, allegorical phraseological units are close to fables, parables and similar texts. Thus, many of these phraseological units go back etymologically to fables and parables, taking them into their imaginative basis as motivators of meanings. In the parable, morality, as a rule, is hidden in the structure of the image and is derived from it through practical reasoning.

One and the same phraseological unit often acts in two forms (in the form of a word combination and in the form of a sentence), for example: to cry stinking fish - Do not cry stinking fish.

Closed sentences of this kind are proverbs, while the corresponding phrases can be called proverbial phraseological units. All allegorical phraseological units, in fact, are proverbial, and vice versa, all proverbs included in the phraseological fund of the language are allegorical. Even in cases where allegorical phraseology does not have a syntactic correlate in the form of a sentence; it still has the character of a proverb as the proverbial character of a language unit is established by a content, rather than a formal criterion.

In allegorical phraseological units, expressive function dominates above the figurative: thus, allegories are created not so much for the sake of their aesthetic self-worth, as for illustrating an abstract idea. Allegory models are not so much a substance (pictorial nuances), but a general role structure of a class of objects. It gives role functions to actors, sets in the minds of recipients a certain mode of comprehension of an extralinguistic object. For example, the same situation "Marriage" can be imagined in different ways: to come to a quiet harbor or to tie the knot.

A characteristic feature of allegorical phraseological units is that they model the role structure of the class of denotative situations. In their figurative basis, the narrative frame of a fable, a parable or an everyday maxim that is behind them is reflected in a condensed form. Allegorical phraseological units, as a rule, denote multi-role situations. The basis for comparison is, first, very extensive, secondly, to a large extent explicated, and thirdly, it contains categorical signs of the theme and image. Being in this plan are close to the symbols, the allegories possess the most powerful potential of modeling reality among the simulative phraseological units.

The frame model of allegorical phraseology usually describes the basis of transference as a large set of interrelated propositions. As an example, let us consider the phraseological unit to bring one's hogs to a bad market.

This phraseological unit is characterized by the presence of lexical and grammatical similarity with the phraseological unit to drive one's pigs to market, but this is only a surface similarity. These phraseological units belong to different subclasses of phraseological models. Phraseological unit to drive one's pigs to market has a metaphorical imagery, and to bring one's hogs to a bad market is allegorical.

Unlike the allegorical phraseological units, in metaphorical ones the basis of the transfer is usually such a semantic feature, which from the conceptual point of view can be secondary, insignificant, although from an aesthetic point of view it is an important sign. 
Possessing a small base of transfer, the phraseological metaphors in general have less potential for modeling reality, rather than phraseological allegories [9]. Metaphorical phraseological units, as a rule, do not model in their imaginative basis the main part of the role structure of the class of denotation situations [10]. The pictorial function prevails over the expressive: they rather "paint" the object, reflect its bright details, than express its conceptual essence.

Due to the above-mentioned features, the meaning and the figurative basis of metaphorical phraseological units, unlike the allegorical ones, often contain different semantic propositions taken from different parts of the general scenario, and the basis for the transfer cannot be seen at all on the surface level.

The structures of the literal and transferred plans are not very similar to each other; hence the almost or complete anisomorphism of the meaning and the image base and as a result all or part of the lexemes have no own transferred meanings.

Due to the dissimilarity of the structures of semantic plans, metaphorical phraseological units are described using a frame that has two subframes: one is for the literal; the other is for the transferred plan.

The subject area of metaphorical phraseological units is not multi-role situations, but mainly states and properties of subjects. Among the metaphorical phraseological units of this kind are, for example: to ride one's high horse, to put on frills, to be flesh and blood, etc.

Comparative phraseological units with a comparative conjunction as do not belong to the verbal ones, but they fulfill the role of the nominal part of the compound nominal predicate in the sentence. We consider them in combination with the linking verb like the verbal phraseological units. In this form, they are close to phraseological metaphors by the way of modeling extralinguistic reality. As the basis of the semantic transfer, they have a similarity (properties / states) of compared extralinguistic objects.

All of them are constructed according to one lexicalgrammatical model (to be) $+<$ qualitative adjective $>+$ as + $<$ noun / substantive group >; the meaning of the adjective's name reflects the integral sign of the image and the theme, and the meaning of the noun or substantive group name is the image of the reference (in the given culture) carrier of this feature.

The similarity of comparative phraseological units contributes to the fact that they all fit into the same abstract model, which has two submodels (possessing the property / state) and further even more specific submodels according to the nature of the properties / states.

\section{Conclusions}

To sum up some results, we should mention that the phraseforming model characterizes the phraseological units generated by it in a number of respects:

1) the degree of the modeling potential;

2) the degree of explicitness / implicitness;

3) the degree of semantic dividedness / integrity;

4) the scale of the denotative area.

Let us dwell on these points in more detail.
1) The modeling potential of similative phraseological unit is its ability to reflect the invariant structure of a class of objects. The more extensive and complex the basis of comparison in phraseological unit, the higher the modeling potential. Its degree can be judged from the amount of information at the top nodes of the frame. As it was shown above, in phraseological allegories, it is generally higher than in phraseological metaphors and comparatives, but the divided metaphors can approach the phraseological allegory in this respect.

2) The degree of explicitness / implicitness of a phraseological unit is the ratio of the volumes of explicit and hidden parts of its semantics. Metaphorical and allegorical phraseological units vary depending on this feature, but as a whole, as our analyses showed, the first are more explicit than the latter.

3) The degree of semantic dividedness / integrity of a phraseological unit is revealed by comparing all the frame slots, reflecting the levels of its structure. The more these levels are homomorphic (that is, the closer they are to isomorphism), the more the phraseological unit is divided. If at least at one of the levels is not homomorphic, the integrity of the phraseology increases. The most divided ones are phraseological comparatives, then - allegories and finally phraseological metaphors, but this is only a trend, and not a rigid pattern.

4) The scale of the subject area of a phraseological unit is a range of situations that can be identified by it. The subject area of a phraseological unit is much broader than the subject area of phraseological metaphors and phraseological comparatives, because of the polyinterpretative character of allegories.

\section{References}

1. V.V. Dobrova, O.A. Kistanova, Issues of cognitive linguistics 1, 114-117 (2017)

2. Ryan M. Nefdt, Language Sciences 54, 43-57 (2016)

3. Talbot J. Taylor, Language Sciences 61, 1-4 (2017)

4. M.V. Nikitin, Lexical word meaning (structure and combinatoric abilities) (Moscow 1983)

5. V.P. Zhukov, Problems of philology 6, 45 (1975)

6. G.L. Permyakov, Basics of structural paremiology (Moscow, 1988)

7. A.F. Losev, Introduction in general language models theory (Moscow, Editorial URSS, 2004)

8. Ya.P. Ignatovich, T.N. Fedulenkova, Yazik i kultura Language and Culture 37, 35-47 (2017)

9. A.Tobing, Cognitive Systems Research 49, 24-32 (2018)

10. M.Landau, Review of General Psychology 22, 62-72 (2018) 